\title{
Vísindastarf á Landspítala - samanburður við Norðurlönd og sóknarfæri
}

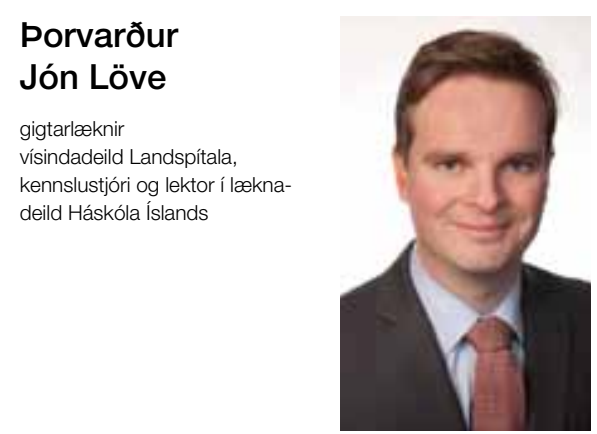

thorvardur@gmail.com

Heilbrigðistengd rannsóknarstarfsemi á Landspítala er gróskumikil og byggir á traustum grunni samstarfs við innlenda og erlenda aðila. Starfsmenn leggja mikiðá sig til pess að sinna vísindaverkefnum samhliða öðrum störfum pótt ekki sé gert ráð fyrir fráteknum tíma til slíks. Ár hvert er pessum starfsmönnum pakkað sérstaklega á viðburðinum Vísindi á vordögum. Pessi dagur er í senn uppskeruhátíð par sem farið er yfir árangur liðins árs og veittar viðurkenningar, en um leið er úthlutað meira en 100 styrkjum til peirra vísindamanna sem lagt hafa fram bestu hugmyndirnar að nýjum verkefnum. Nú pegar pessi ánægjulegi dagur er að baki gefst færi á að meta stöðuna í vísindastarfi á Landspítala í dag, blikur á lofti og tækifæri næstu ára til frekari sóknar.

Vísindadeild Landspítala hefur komið á verklagi til pess að mæla afrakstur vísindastarfsins, auk pess að starfa með NordForsk að slíkri tölfræði fyrir Norðurlöndin. Pær tölur sýna að fjöldi birtra vísindagreina frá spítalanum eykst ár frá ári. Petta bendir til pess að sú framsýni sem stjórn Landspítala sýndi með pví að skera ekki niður framlög til vísindastyrkja í prengingum undanfarinna ára hafi skilað sér. En sitt er hvað, magn og gæði, og pví parf að svara hvort petta tvennt haldist í hendur. NordForsk hefur nú birt sína nýjustu skýrslu ${ }^{1}$ um vísindastarf á Norðurlöndum og beitir við pá vinnu vandaðri aðferðafræði. Pegar fjöldi birtra greina er talinn er tekið tillit til fjölda höfunda frá hverri stofnun miðað við heildarfjölda höfunda greinar pannig að ef stofnun á einn höfund af 25 telst hún aðeins hafa birt 0,04 greinar. Pegar tilvitnanir eru svo taldar eru allar sjálfstilvitnanir útilokaðar og fjölda tilvitnana í hverja grein er deilt í meðalfjölda tilvitnana í greinar á heimsvísu í sama fagi. Pannig fæst mælikvarði par sem talan 1 merkir að fjöldi tilvitnana í grein er jafn heimsmeðaltalinu. Pessi mælikvarði gerir kleift að bera vísindastarf á Íslandi beint saman við önnur Norðurlönd og heiminn allan án nokkurrar forgjafar vegna smæðar landsins eða annarra pátta. Мeð öðrum orðum: hér eru gæði mæld beint en ekki miðað við höfðatölu.

раð er ánægjulegt að greina frá pví að árin 2000-2003 og 2004-2007 var Landspítali með hæstu tilvitnanaeinkunn af öllum háskólasjúkrahúsum á Norðurlöndum, eða 1,31 og 1,33 á peim kvarða sem lýst var hér að framan. Hins vegar er áhyggjuefni að tímabilið 2008-2011 hefur pessi einkunn lækkað í 1,07. Pótt einkunnin sé yfir heimsmeðaltali hefur Landspítali nú fallið í 15. sæti af 21 háskólasjúkrahúsi á Norðurlöndum og er undir meðaleinkunn Norðurlandanna. Pó að hjá smárri einingu á borð við spítalann geti sveiflur milli tímabila verið umtalsverðar er óráðlegt að horfa framhjá pessum niðurstöðum. Pegar gögnin eru greind nánar kemur í ljós að líklega er hallinn aðallega á sviði pess sem skilgreint er sem heilbrigðisvísindi (health sciences) en par er átt við klínískar og faraldsfræðilegar rannsóknir, en síður á sviði lífvísinda (biomedicine). Раð er mikilvægt að styðja áfram rannsóknir starfsmanna spítalans í lífvísindum. En sóknarfæri í styrkingu rannsókna á Landspítala liggja ekki síður í rannsóknum á sviði heilbrigðisvísinda. Par er lykilatriði að bæta aðgengi rannsakenda að rannsóknargögnum.

Rannsakendur á sviði heilbrigðisvísinda purfa greiðan, öruggan og ódýran aðgang að gögnum. Nú er pví svo háttað að vegna rannsóknar getur purft að senda gögn milli stofnana með kennitölum, mismun- andi aðferðum er beitt við samtengingar, og vísindamaðurinn ber stundum sjálfur ábyrgð á að tengja saman gögn og gæta persónuöryggis. Engin leið er að gera fyrirspurnir í rannsóknargrunna án atbeina sérfræðinga sem forrita hverja spurningu sérstaklega. Petta ferli felur í sér götótta persónuvernd, er dýrt, tímafrekt og sama vinnan er endurtekin. Einkafyrirtækið Íslensk erfðagreining hefur leyst petta mál fyrir sína rannsakendur. Par er pess gætt að fyrirtækið og rannsakendur pess hafi aldrei aðgang að persónuauðkennum með pví að láta priðja aðila um samtengingar og dulkóðun. Jafnframt fá rannsakendur fyrirtækisins beinan aðgang að kerfi sem gerir ópersónugreinanlegar rannsóknarfyrirspurnir mögulegar. Til pess að allir íslenskir vísindamenn geti notið sams konar aðstæðna parf að skipuleggja ferli sem gegnir pví hlutverki að dulkóða, hreinsa og samtengja rannsóknargögn og afhenda vísindamönnum pau án persónuauðkenna. Einnig parf að gera vísindamönnum kleift að gera sjálfir fyrirspurnir í rannsóknargrunnum. Nýlega sampykkt lög um vísindarannsóknir, lífsýnasöfn og söfn heilbrigðisupplýsinga auðvelda slíka uppbyggingu, ekki síst ákvæði um leitargrunna.

Rannsakendur á Landspítala vinna vísindastörf par sem magn og gæði standast alpjóðlegan samanburð. En nú er tækifæri til að sækja fram með pví að vinna eftir skipulegri sýn pegar kemur að notkun vísindamanna á gögnum til rannsókna. Pannig tryggjum við persónuöryggi, gæði og hagkvæmni heilbrigðisvísinda á Íslandi.

1. Comparing Research at Nordic Universities using Bibliometric Indicators. NordForsk 2014. ISSN 1504-8640

- 20

Research at Landspitali University Hospital - Comparison with the Nordic Countries and New Opportunities Porvarður Jón Löve MD, MMSc, PhD Rheumatologist, Landspitali University Hospital Assistant Professor and Director of Education, Faculty of Medicince, University of Iceland 